\title{
The Essence of Legal Education in Indonesia: A Critical Appraisal
}

\author{
Emmilia Rusdiana* \\ Department of Law, Faculty of Social \\ Sciences and Law \\ Universitas Negeri Surabaya \\ Surabaya, Indonesia \\ emmiliarusdiana@unesa.ac.id
}

\author{
Pudji Astuti \\ Department of Law, Faculty of Social \\ Sciences and Law \\ Universitas Negeri Surabaya \\ Surabaya, Indonesia \\ pudjiastuti@unesa.ac.id
}

\begin{abstract}
Judicial corruption continues to occur and has increased, and data shows that the most corrupt education is from jurist, so one of the highlights is aimed at legal education pursued by law enforcers. This study attempts to analyse the essence of legal education in Indonesia. This research is a normative legal research and obtained by studying the documentation and literature of the study and with the collection of data from the literature study and analysed prescriptively. The authors believe the essence of education is to realize one's personal skills and competence and personality, and the essence of law is based on justice and happiness to regulate society by promoting morality, while the essence of law enforcement is to have a role model of society because of the legal professionalism so the essence of legal education is to shape one's good personality.
\end{abstract}

Keywords-The Legal Education, the Essence of Law, the Essence of Education, Personality

\section{INTRODUCTION}

Corruption is long standing problem in the global economy. Corruption reduces economic growth and private investment, and it limits well being through depressed per capita income, increased child morality, and illiteracy. One method of addressing the issued raised by corruption would be to teach student about the subject. This approach was advocated in the 2014 Poznan Declaration, a formal statement aimed at mainstreaming ethics and anticorruption in higher education [1].

A more surprising phenomenon is the emergence of the phrase judicial corruption. This has been stated by Frans Winarta's [2] article on judicial corruption lays much of the blame for the tragic state of the Indonesian judiciary precisely where it belongs - with those in the legal profession who work to undermine the judicial system. It is indeed a tragic state of affairs where lawyers can openly boast that they can guarantee a judicial outcome, and taunt their opponents with the inevitability that those opponents will lose, not because of the legal arguments, but because of the inadequacy of judicial salaries. It is a tragic state of affairs when two courts at first instance in two different parts of the country reach virtually word-for-word identical judgments, each totally absurd as a matter of jurisprudence, and where the only link between the two courts is the plaintiffs' lawyer. The odds of those identical judgments being genuinely arrived at are similar to the odds of a room full of young children accidentally typing the works of Shakespeare. yet all these things.

The Faculty of Law, University of Indonesia [3] is expected to give contribution to anti-corruption lawyers, law practitioners, or law enforcers, by strengthening ethics matters, for example Professional Responsibility courses and later subjects related to anti-corruption, because actually corruption is multi. This is done in order to produce anti-corruption attitudes that are put in all fields of law.

Marsudi Triatdmodjo from the University of Gajah Mada Yogyakarta stated that law enforcement officers in Indonesia are immoral because the teaching of law in almost all universities in Indonesia is incomplete, namely minimal regarding skills and values, while people who work in the field of law, such as advocates, prosecutors and judges or employees/officials in the field of justice. Law faculties that educate prospective law enforcement/legal professionals, even after graduating in various professional environments and their respective activities that can influence behaviour. however, the process during higher education in law is certainly an important factor for the development of jurist who have credibility, capacity and have an anti-corruption mentality.

All legal education at the Faculty of law is directed at mastering legal knowledge, ranging from introduction to legal science, introduction to Indonesian law, state administration law, civil law, criminal law, Islamic law, and so on. All of the material is a provision of knowledge as well as being equipped with good skills to be ready when practicing specifically in the field or profession of law, and the law faculty has taught these skills or legal skills through various subjects, such as legal practice that is strengthened by consulting / legal aid institutions, and it is classified as education and training in legal skills, as well as the choice of dispute resolution, preparation of trade contracts, and so on. While higher education in law equips students with the values of truth and professional ethics by giving courses that are professional responsibilities which then become ethical and professional responsibilities.

Actors classified as judicial corruption are judges, prosecutors, police and ironically, most judicial corruption is a law degree, and they have taken legal education. One effort to prevent the existence of JC is to restore the true essence of legal education. The legal education is education 
intended for someone who wants to become an expert in the field of law, the purpose is not only produced by legal experts who know the ins and outs of legal rules, the application of law and filling institutions in the field of law, but also creates and develops the law through the teachings of the law (legal doctrine) and legal analysis [4], so that legal education can only be followed by selected people who have proven their insights, skills and integrity, this learning should have learning about the essence of Education, the essence of law and the essence of jurist. The problem of this research is the challenge for legal education to return legal education to the essence of legal education itself.

The design of study is to show the discourse of the essence of legal education by exploring the essence of education and law itself.

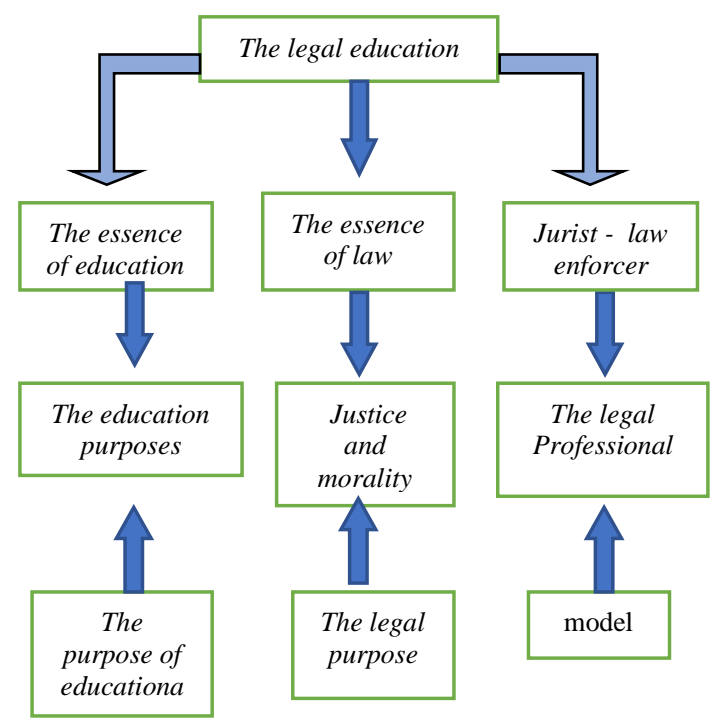

\section{RESEARCH METHODS}

Method of Data Analysis that Legal research is intended to explore and seek the truth [5]. This research is a normative legal research, which provides a prescription analysis. The research uses Legislation approach, the concept and philosophy, and philosophy is to seek and think of the essence of truth profusely [6]. The special character of the philosophical study of legal science is to find the essence law and justice [7]: In this legal research, primary legal material[8] becomes very important in the context of basic orientation, with secondary legal material and tertiary as a means to enrich the analysis of studies in this. This research was obtained by studying documentation, discussion, and literature study. The Documentation technique to trace the provisions of the laws and regulations in Indonesia Literature techniques to find concepts, teachings, doctrines, philosophies, and principles of law, which are the work of jurists. These three techniques or methods will result in justification of the household, family, paradigm and ideology which form the basis of values. This research will provide a prescription[9]. This study is the flow of thought from the view of legal research using qualitative juridical analysis methods[10] The analysis can give significant meaning to the analysis of legal material, which can explain the pattern of description, and look for relationships between the dimensions. Prescriptions in statutory regulations, an analysis of legal materials with a hermeneutic perspective, interpretations, including interpretations: authentic, grammatical, systematic, sociological, teleological, functional or futuristic.

\section{RESULT AND DISCUSSION}

The essence of education can be discussed in the definition of education, The educational purpose and the purpose of the educational institution itself. Definition of education [11] is a deliberate effort from parents who are always interpreted as capable of giving moral responsibility to all their actions. Education [12] is an activity to improve the general knowledge of a person, including in improving the mastery of theory and skills, deciding and finding solutions to problems involving activities in achieving its purposes, be it problems in the world of education or everyday life.

Educational purposes according to Article 3 of Law No. 20 of 2003 concerning the National Education System, that the purpose of national education is to develop the potential of students to become human beings who believe and fear God Almighty, have good morality, health, knowledgeable, capable, creative, independent, and become democratic citizens. and responsible. According to $\mathrm{Ki}$ Hadjar Dewantara education as guidance in the life of growing children, meaning that education guides all naturals forces that exist in these children, so that they as humans and as members of society can achieve the highest safety and happiness. Education as a guide not only makes a child get a higher and broader intelligence, but also distances himself from evil deeds [13].

According to Ki. Hajar Dewantara, based on its foundations known as the Pancadharma [14], consisting of the foundations of nature (human nature is part of the universe), liberty (life should be full of happiness and peace), nationality (one's) must feel one with his people and in the sense of unity cannot be contrary to humanity), culture (human beings are cultural beings), and humanity (the importance of friendship with other nations).

A number of articles have concluded that the concept of Education in the context of Ki Hajar Dewantara is relevant to Islamic Religious Education [15], and $\mathrm{Ki}$ Hadjar's multicultural education was nationalistic and universal in nature [16]. One of the main purposes [17] of the educational institution is to enable a person/student to become active, independent and responsible, to promote the personal skills and competences (including knowledge, skills and values) of a student, enabling them to shape their own and the community's life independently, critically.

Education [18] should be directed to: 1). Internal and inner independence (thus becoming a person who has intellectual autonomy, existential autonomy, social autonomy). 2) Build students' awareness that they are an integral part of the universe. 3). Form the feelings of 
students to love order and peace. 4). Forming an attitude of responsibility in students to be loyal and responsible in maintaining the values and forms of national culture. 5). Build a sense of nationalism in students so that they feel one with the people and love for their people. 6). Building a sense of brotherhood in students on a planetary scale (crossborder) so that through the nobleness of the intellect and the clarity of conscience grows a feeling of love for fellow human beings. The conclusion is that the essence of education is based on the definition of Education and the purposes of the Educational Institution lead to the purpose of Education itself, namely personal skills and competence and good personality.

The essence of legal education can also be viewed in the perspective of the essence of law and the purpose of the law itself. Law has various definitions and has been defined by experts to man on the street (common people), so law experts agreed to disagree in giving a definition of law. There are several reasons why definition of law is not easy to made:

a. Existence and substance of law is abstract. According to Krabbe[19], that originate in the legal sense and obtain power only from its suitability with the individual legal sense, and also law as the society norm must control all society members so they lean on common law conviction. There are many color of the norms and many rules exist in society so the uniformity in the legal norms is more important than the content of the rule. Therefore, our legal awareness provides the highest values to the unit of the norm in order to achieve purposes that arrange society.

b. Aspect and dimension of law is broad. Ubi societas ibi ius means law exists in the people exist. Humans were created as social beings who need each other and in their socialization is efforts to survival. In their socialization. In the human society, there are two aspects [20] which physical aspect and existential aspect. Physical aspect refers to human nature as creature who physically really alive. As for existential aspect related to the existence of different with other living beings.

c. Differences in comprehension and perception. Perception discusses about law from various disciplines. Thus, discussion about law can be proposed by historians, sociologists, psychologists, anthropologists, politicians, philosophers, or other disciplines. While comprehension about law must be comprehensive to avoid the false discussion because of partial comprehension.

A discussion about definition of law must be completed by the legal essence which is as follows:

a. Legal principle. It constitutes the broadest foundation for the birth of rule of law or ratio legis of rule of law. Legal principle will not be lost its power because of generating law but will exists continuously and generating a next law [21].

b. A legal norm or code of conduct or guidance of conducts or guideline of behaviors is a set of rules about how humans, either as an individual or a member of society should behave. Function of norm as society life support to reach the purpose of life.

c. Rule of law. A legal norm can be distinguished based on its form that is the written rule of law and unwritten rule of law. Rule of law constitutes manifestation of a legal norm. Rule of law is only one of symbols used by a legal norm to show itself. Rule of law as the most complete means to express what is required by a legal norm.

The Teleologi law may teach three theories legal objectives which include [22]:

a. Ethical theory emphasizes the purpose of a moral-ethical nuance both for individuals and society as a whole. in this theory justice is emphasized as the purpose of law. this is because the content of the law is considered to be determined by ethical beliefs about what is fair (justice) and unjust (un justice)

b. Utility theory emphasizes the purpose of the law that provides maximum (happiness the greatest). this theory is adopted by the flow of utilitarianism which emphasizes expediency as a legal objective.

c. Mixed theory seeks to strike a balance between the aims of law.

The essence of technology-related legal education resulted in criticism from Edmon Makarim, that viewpoint that higher education law must follow fully the demands of the market, this is not fair because market-its misguided era of technology disruption does not make higher education law misdirected. Educational philosophy that contributes to the development of culture and civilization must be maintained, so that legal people are not subject to technology, but can also say what technology should be developed [23]. The global challenges of the industrial revolution 4.0 and society 5.0 do not make Indonesia's legal education lose ground, and technology is not always right, business is not always right, law must come first.

The essence of the law is based on the definition and purpose of the law based on justice and happiness with the main purpose being to regulate society by promoting morality. So legal education equips students with the values of truth and professional ethics, and students are ready to cooperate the legal profession with a bad environment.

The similarity between learning in legal education crosses the nature of education, the essence of law and its relation to technology. Legal education is not specific to legal science, but there must be learning oriented not only to having the skills, skills and expertise of the law, but also having the character as a personality that is good.

Law enforcers are called professionals because their ability to think and act is beyond written law without hurting the value of justice. In upholding justice, it is required the ability of law enforcers to criticize the law and practice of law in order to find out what should be done as a professional. Second, professional violations never disappear; but its development can be prevented. It should be noted, the quality of commitment depends on the ability 
to build positive self-image and be a reflection of the importance of self-esteem as a value. Awareness of the importance of positive self-image and self-esteem as values will help a legal professional not easily trade his profession. That is, expertise is not enough. The virtue is needed to be professional, dare to uphold justice. Consistency in acting fairly creates the habit of being fair. Third, the virtue of being fair becomes evident not only through fair treatment of the interests of the community, but also through the courage to become a whistle blower when there is a professional practice. A professional should not silence unethical actions of colleagues. This part of carrying out the task is not easy, but must be done because the ability to be fair requires courage to practice, not just knowing justice [24].

Law enforcement requires a professional attitude, competent, honest, and wise, because they have the responsibility of upholding the authority of the law and upholding justice. Professionalism of law enforcement can be seen from the level of mastery of legal knowledge, skills and personality of law enforcers in carrying out their duties and authority at work. So legal professionalism can be a role model for the community when good skills/ expertise and personality are already possessed by law enforcement.

\section{CONCLUSION}

The conclusion of this study that the essence of education is based on the definition of Education and the purposes of the Educational Institution lead to The educational purpose itself namely personal skills and competencies as well as one's personality, and the essence of law based on the definition and purpose of the law based on justice and happiness with the main purpose is to regulate society by promoting morality. while the essence of law enforcement is to have an example for the community because of the legal professionalism in the form of good skills/expertise and good personality.

The Contribution of this paper can be used as a guideline for the government through the national education ministry that the higher education and is responsible for the sustainability of education in the university, especially legal education. The concrete is in the form of compiling its authority to arrange policies in accordance with the results of this study, namely curriculum or learning or activities in legal education not only focus on improving the skills and skills of the legal field but also prioritizing curriculum or activities or learning aimed at morality and justice in order to realize personality the good one. The other contribution is to inspire lecturer to be always aware of its role as a model for student university.

\section{REFERENCES}

[1] Alice Jihansson, The Posnan Declaration Featured in Times Higher Education and University World News (Quality of Government Institute), University Of Gothenburg, 13 November 2014.

[2] LSM, Judicial Corruption: where are we going? http://www.1smlaw.co.id/index.php?option=com_cont ent\&task=view\&id=200\&itemid=18\&lang=en. 2012. from The Jakarta Post, Oct. 31, 2005.

[3] Topo santoso. Pendidikan Hukum Kita. https://law.ui.ac.id/v3/pendidikan-hukum-kita/. 6 April 2016.

[4] Yudi Widagdo Harimurti, Korelasi Jenjang Pendidikan dalam Mencetak Sarjana Hukum yang Kompeten dan Berperibadian, the book of Arah Pendidikan Hukum, Malang, Setara Press, Intrans Publishing, 2015.

[5] Istanto, Sugeng, Penelitian Hukum, Yogyakarta, CV. Ganda, 2007.

[6] Surbakti, Natangsa, Filsafat Hukum Perkembangan Pemikiran dan Relevansinya dengan Reformasi Hukum Indonesia, Surakarta, BP-FKIP UMS, 2012.

[7] Sidharta, Penelitian dalam Perspektif Normatif, Semarang. The paper of Seminar Nasional, Metodologi Penelitian dalam Ilmu Hukum, Bagian Hukum dan Masyarakat Fakultas Hukum Undip, 2010.

[7] Sunggono, Bambang, Metodologi Penelitian Hukum, Jakarta, Raja Grafindo Persada, 1997.

[9] Marzuki, Peter Mahmud, Penelitian Hukum, Jakarta : Prenada Kencana, 2008.

[10] SW.Maria. Sumardjono, Pedoman Pembuatan Usulan Penelitian Sebuah Panduan Dasar, Jakarta, Gramedia Pustaka Utama, 2001.

[11] Muhibbin, Syah, Psikologi Pendidikan Dengan Pendekatan Baru, Bandung, PT. Remaja Rosdakarya, pp. 11, 2007.

[12] Heidjrachman and Suad Husnan (Ed. 4), 2011, Manajemen Personalia, Yogyakarta: BPFE.

[13] Suparto Rahardjo, Biografi Singkat Ki Hajar Dewantara, 1889-1959, Yogyakarta: Garasi, PP, 6, 2009.

[14] A.R. Tilaar, M.Sc. Ed, Pendidikan Kebudayaan Dan Masyarakat Madani Indonesia, PT. Remaja Rosdakarya, Bandung, pp. 132, 1999.

[15] Wawan Eko Mujito, Konsep Belajar Menurut Ki Hadjar Dewantara Dan Relevansinya Dengan Pendidikan Agama Islam, Jurnal Pendidikan Agama Islam, Vol. xi, No. 1, Juni 2014, Pp. 75.

[16] Muthoifin, Pemikiran Pendidikan Multikultural Ki Hadjar Dewantara, Jurnal Intizar, Vol. 21, No. 2, 2015, pp. 317

[17] Živilè Vilma Jonynienè, Lina Petrauskienè. The Role of Legal Education in Development of Students Personal Competences: Conceptions of 10-12 Grade Students And School Staff. Social Work, Research Journal. Vol 12, No 1 (2013). ISSN Online 2029-2775.

[18] Bartolomeus Samho, Oscar Yasunari, Konsep Pendidikan Ki Hadjar Dewantara dan TantanganTantangan Implementasinya di Indonesia Dewasa ini, Lembaga Penelitian dan Pengabdian Kepada Masyarakat, Universitas Katolik Parahyangan Bandung, 2010.

[19] L.J. Van Apeldoorn, Pengantar Ilmu Hukum, Jakarta, Pradnya Paramita, pp. 439, 2001.

[20] Peter Mahmud Marzuki, Pengantar Ilmu Hukum, Jakarta, Prenada Media Group, pp. 42, 2011. 
[21] Paton G.W, A Text Book of Jurisprudence, London, Oxford University Press, 1964.

[22] I Dewa Gede Atmadja, Filsafat Hukum: Dimensi Tematis dan Historis, Malang: Setara Press, pp 36, 2013.

[23] Norman Edwin Elnizar, 2019 , https://www.hukumonline.com/berita/baca/lt5de0c865 c29a7/dekan-fh-ptn-se-indonesia-rombak-profillulusan-hukum--seperti-apa.
[24] Andre Ata Ujan, Quo Vadis Profesionalisme Hukum?. Article Pusat Pengembangan Etika Atma Jaya Jakarta, Kompas, 12 Agustus 2005. 